\title{
Application of Standardization and Lean Production Methods for the Development of Management Systems at Machine-Building Enterprises
}

\author{
Ivan V. Emanakov 1*[ORCID 0000-0001-8189-2458], \\ Sergei A. Ovchinnikov 1[ORCID 0000-0003-3877-1946]
}

\author{
${ }^{1}$ All-Russia Scientific and Research Institute "Center”, Moscow, Russia \\ emanakov2@yandex.ru
}

\begin{abstract}
Particular features of the organization of management processes at modern machine-building enterprises are considered in this paper. It has been established that in order to increase the efficiency and effectiveness of organizing the production of scientifically advanced products, it is necessary to unify the principles and tools used in solving production management problems at all stages of the product life cycle. The applicability of the concept, methods, and tools of lean production for the development of management systems of machine-building enterprises has been substantiated. A systematic analysis of the regulatory and technical base of national standardization in the field of lean production has been carried out. The classification features for the grouping of documents on the standardization of tools and approaches of lean production have been determined. A brief description of the main standards and the interconnections of their requirements when building a lean production management system is presented. A model of the production system of a machine-building enterprise has been formalized, which includes the following organizational elements: goals and tasks of management, objects and subjects of management, levels of management, external and internal requirements, processes. The model allows us to form an optimal approach to improving the efficiency of management processes based on standardization. The analysis of the level of development of production systems of machine-building enterprises in the field of development, production, and supply of scientifically advanced products has been carried out. Based on the results of the analysis, the key processes affecting the production system of the enterprise have been identified: planning, material and technical support, instrumental support, production. A development concept for the production system of a machine-building enterprise has been proposed, which is based on the methodology of Balanced Scorecard on the key areas of the organization's activities: development potential, external environment, processes and management system, financial results. The proposed concept takes into account the peculiarities of modern scientifically advanced production. The practical implementation of the concept allows for the organization of flexible production mechanisms with a low production unit cost.
\end{abstract}

Keywords: machine building, production system, standardization, quality, technology, lean production

\section{INTRODUCTION}

One of the most advanced concepts for managing a production system at modern machine-building enterprises is the concept of Lean Production, which combines various management methods and tools, and is of both practical and scientific interest [1].

Lean production is aimed at eliminating losses in all areas of the organization's activities [2, 3], including building relationships with consumers, product design, supply chain building, production management, transport and logistics operations. At the same time, losses are understood as any action during which resources are consumed, but the value is not created for the consumer of the product.

When implementing lean production, increased attention is paid to the constant reduction of the time required to perform all types of activities at the company, while ensuring quality improvement, cost reduction, and faster response to changes in external 
and internal factors affecting the organization's production processes $[4,5]$.

The analysis of lean production implementation results in large holdings of Russian mechanical engineering (aviation, shipbuilding, engine building) [6] has shown that enterprises have developed various types of production (from experimental to large-scale) for various groups of manufactured products. At the same time, the management of production systems does not have time to adapt to production conditions [7]. Automation of individual control processes is carried out without the development of a general concept of the entire control system, which creates duplicate unsynchronized data sources and does not exclude duplicate functions of structural units.

The relevance of research in this area is determined by:

- increasing requirements for the organization and ensuring the effective functioning of machine-building enterprises producing scientifically advanced products for general and special purposes, taking into account the harmonization of various procedures for managing production processes;

- the need for a unified scientific and methodological approach to the implementation of the lean production concept based on the standardization method in order to increase the efficiency of the management system of a machine-building enterprise;

- the need for in-depth study of scientific, methodological, and analytical approaches used in the implementation of lean production methods in accordance with the requirements of national standards.

\section{MATERIALS AND METHODS}

The purpose of the study is to analyze the main features of the management of machine-building production, to formalize the model and concept of production system development (hereinafter - PSD) at machine-building enterprises, based on the use of lean production methods, taking into account the requirements of national standardization.

The objectives for the study are the following:

- analysis of lean production methods and the peculiarities of their application in scientifically advanced industries;

- study of the current regulatory and methodological framework for national standardization in the field of lean production;

- development of a scientific and methodological apparatus for standardizing the management system of a machinebuilding enterprise on the basis of lean production methods;

- formation of scientifically based recommendations and applied solutions for the practical application of lean production methods in the development of the management system of a machine-building enterprise.

To achieve the objectives defined, the methods of applied system analysis, expert assessments, and classification have been used.

The applied methodological apparatus allows us to generalize and regulate the procedure for applying lean production methods, taking into account the organizational and technical features of various stages of the life cycle of scientifically advanced products.

\section{RESULTS}

\subsection{Features of machine-building production management}

The management system of a modern machinebuilding enterprise should be built in such a way as to ensure the fulfillment of the main operational function - the development and production of scientifically advanced products (works, services) necessary for the customer in a timely manner, with a given level of quality and an agreed price.

The specifics of managing the development, production, and supply of scientifically advanced products (works, services) at a modern machinebuilding enterprise are shown in Figure 1.

At the moment, machine-building enterprises most often form the production system independently - it is a "historically" established management system, which "does not have time" to adapt to changing production conditions and increasing consumer requirements.

To increase the efficiency of the functioning of certain areas in the structure of machine-building enterprise activities, the formation of production systems and their management should be based on common principles and management techniques in order to streamline the mechanism for making managerial decisions by top management [8-10]. 


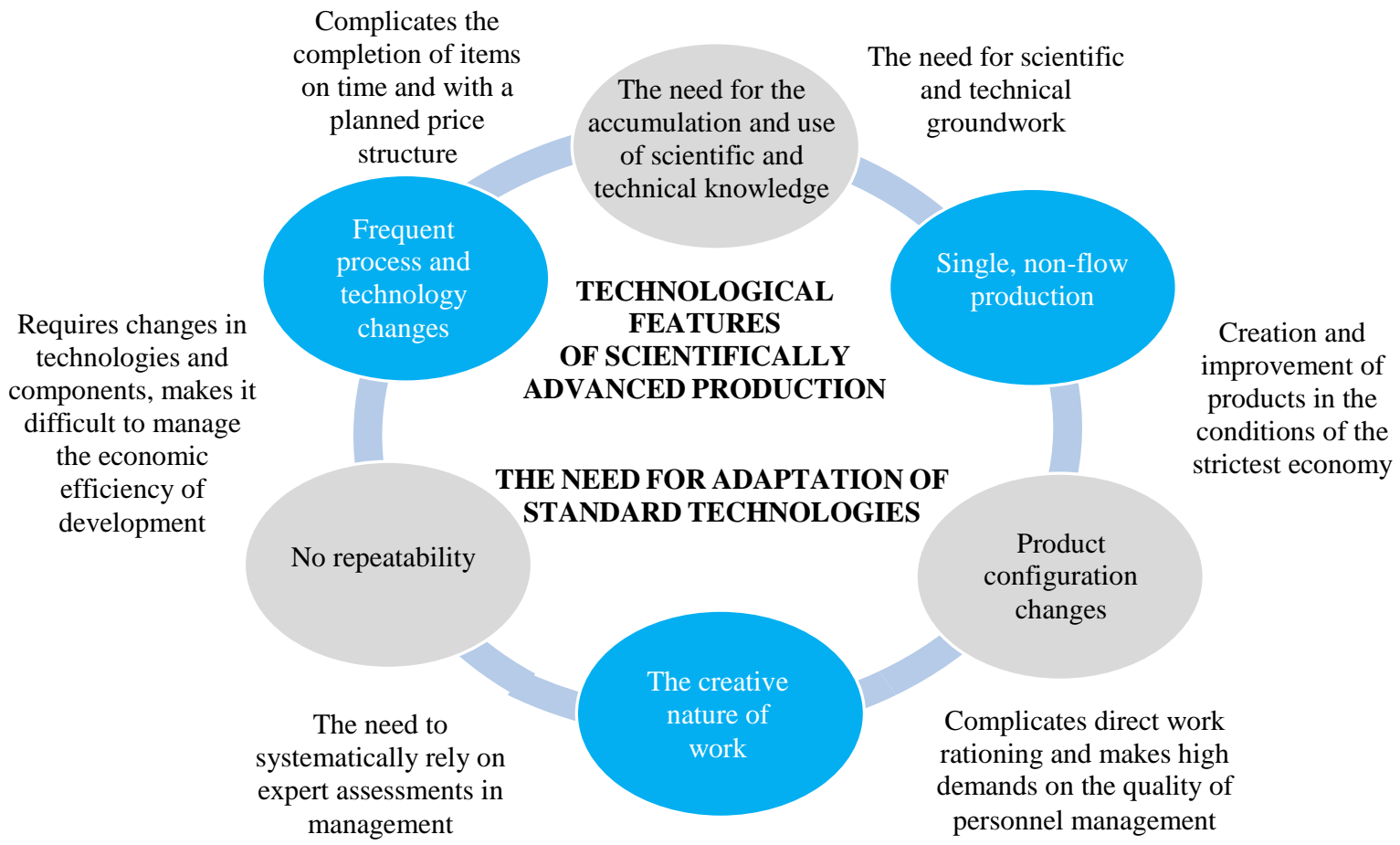

Figure 1. Features of development, production, and supply management of scientifically advanced products (works, services)

Source: Compiled by the authors

To do this, a mechanism for standardizing the management model in the selected areas should be implemented, taking into account the adaptation of the best production practices and the requirements of scientifically advanced industries.

\subsection{Regulatory framework for standardization in the field of lean production}

Despite the proven effectiveness of the implementation of lean production methods, today there are no international standards for the Lean production concept. The US Society of Automotive Engineers (SAE) standards for lean production, such as SAE J4000 Identification and Measurement of Best Practice in Implementation of Lean Operation and SAE J4001 Implementation of Lean Operation User Manual, have gained some recognition. These standards are a tool for identifying and evaluating best practices for implementing lean production activities in industrial organizations.

The regulatory and technical base for standardization in the field of lean production in the Russian Federation is made up of national standards developed in 2015-2020.

A detailed analysis of the developed standards allows us to conditionally divide them into four groups:
1) Standards for terminology and general provisions of lean production;

2) Standards for a lean production management system (LPMS) - general LPMS requirements, LPMS audit/assessment, LPMS certification, as well as requirements for the integration of LPMS and quality management systems (QMS);

3) Standards for the main methods and tools of lean production, including personnel training in this regard;

4) Standards for the main features and requirements for the application of lean production in organizations of various industries (automotive, shipbuilding, aircraft sectors) and forms of management (integrated structures, supply chain cooperation).

The first group of standards includes GOST R 56020 Lean production. Fundamentals and vocabulary.

The second group of standards includes:

- GOST R 56404 Lean production. Requirements for management systems;

- GOST R 56405 Lean production. Certification process of management systems. Assessment procedure; 
- GOST R 56406 Lean production. Audit. Questions for assessment management system;

- GOST R 57522 Lean production. Guidelines for integrated quality management system and lean production.

The third group of standards includes:

- GOST R 56407 Lean production. Basic methods and tools;

- GOST R 56906 Lean production. Workspace organization method $(5 \mathrm{~S})$;

- GOST R 56907 Lean production. Visualization;

- GOST R 56908 Lean production. Work standardization;

- GOST R 57523 Lean production. Guide for personnel training system;

- GOST R 57524 Lean production. Value stream.

The fourth group of standards includes:

- GOST R 58524 Lean production. Special requirements for the use of lean production in organizations and supply chains of the automotive industry;

- GOST R 58581 Lean production. Special requirements for the application of lean production in aerospace industry, operating and service organizations;

- GOST R 58589 Lean production. Special requirements for the application of lean production in the shipbuilding industry;

- GOST R 59017 Lean production. Guidance for use of GOST R 56404 requirements in integrated structures;

- GOST R 59018 Lean production. Guidance for the use of GOST R 56404 requirements in the supply chain.

As the analysis has shown, standards on lean production are intended for use by any organization in various industries, regardless of their type, size, products supplied and services provided.

\subsection{Model of the production system of a machine- building enterprise}

The production system of a machine-building enterprise is a set of interrelated and interacting production, control, and support processes aimed at meeting the customer's needs at all stages of the product life cycle, achieving the established goals in all types of production activities, and ensuring the effective functioning of the enterprise.

The model of the production system of a machine-building enterprise is based on the principle of the structural arrangement of the main elements necessary for a holistic description of the production activity of the enterprise.

The main elements of the model of the production system of a machine-building enterprise are presented below.

Management objectives:

- ensuring the quality of manufactured products at the level of domestic and world practices;

- ensuring the efficiency of the enterprise at the level of domestic and international standards.

Management tasks:

- elimination of temporary "losses" in the main production and supporting processes of the enterprise;

- reduction of the levels of hierarchy when making managerial decisions in the current organizational structure of the enterprise;

- formation of standard operating procedures for the execution of manufacturing operations and technological functions;

- reducing deviations from standard operating procedures;

- increasing the turnover of inventories.

The object of management in the production system of a machine-building enterprise is a product at all stages of its life cycle.

The subjects of management are:

- government customers, foreign customers, consumer organizations;

- enterprises of integrated structures (holdings) to the level of structural divisions;

- enterprises that are part of cooperation for the development, production, warranty, and service of products.

The production system of a machine-building enterprise is managed at the following levels:

- holding; 
- company;

- workshop/department;

- area/sector/bureau;

- working center/workplace

External requirements for the production system of a machine-building enterprise are defined in:

- regulatory legal acts governing the requirements for individual stages of the life cycle of products;

- national and state military standards, including general technical, organizational and methodical systems and sets of standards that determine the requirements for design and technological production preparation, for the development and launching products into production, for quality control and management in the production process, for labor protection, for industrial and environmental safety, for the methods and technologies of lean production;

- regulations governing the activities of industrial enterprises.

Internal requirements for the production system of a machine-building enterprise are defined in:

- industry strategies;

- programs and development plans;

- enterprise standards;

- methodological and regulatory documents (methods, regulations, instructions, rules, process maps, etc.);

- standards and indicators of the production activity of the enterprise.

In accordance with the results of the industry analysis of the current state of the level of development of production systems at modern machine-building enterprises, the following priority processes in the organization of production systems have been identified:

1) production planning;

2) provision of materials and purchased components;

3) instrumental production support;

4) product manufacturing.

Production planning
In the conditions of a long development, production, and delivery cycle of products, the complexity of technological operations and the need for continuous logistics of the production process, as well as taking into account existing legal requirements and restrictions, the procedures for planning and monitoring organization core activities throughout the entire product life cycle play a key role.

Provision of materials and purchased components

One of the principles of effective management of production processes is the rational material and technical production support, including with the aim of minimizing costs associated with excessive volumes of production stocks and suboptimal schemes for their use.

\section{Instrumental production support}

Organization of consistent and purposeful activities to improve production instrumentation efficiency to create transparency in the structure of instrumental support stocks and improve the quality of planning of production and logistics processes and material flows.

\section{Product manufacturing}

The transition to a production system based on the principles of lean production allows both production and service enterprises to achieve significant strategic results without additional investment (using only their own resources).

\subsection{The concept of development of the production system of a machine-building enterprise}

The concept for the development of the production system of a machine-building enterprise determines the basic principles, key goals, and objectives, directions, and mechanisms for the development of the production system of the enterprise in a single management structure in order to ensure and maintain efficient production of competitive products.

The goals in the field of development and optimization of the production system of a machinebuilding enterprise, ensuring the implementation of the main strategic goal, are grouped according to the principles underlying the Balanced Scorecard (BSC) methodology and are detailed by area.

The conceptual structure of goals in the field of development and optimization of the production system of a machine-building enterprise is shown in Figure 2. 


\section{Main Strategic Goal}

Reduce the time of development and production of products with a given level of quality and cost

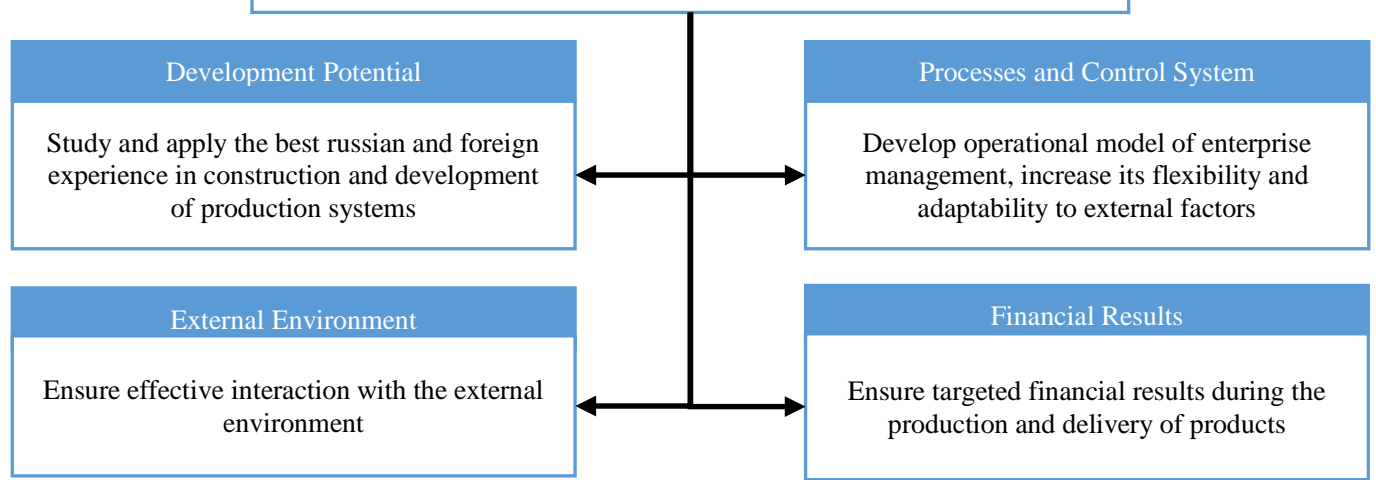

Figure 2. The conceptual structure of goals in the development and optimization of the production system of a machine-building enterprise

Source: Compiled by the authors

Improving the production system of a machinebuilding enterprise is associated with constant development and adaptation to changes in the external environment, new goals, objectives, requirements and is implemented by:

1) development of human resources and changes in the personnel;

2) adjustments, optimizations, and changes in internal requirements;

3) modernization, optimization, and changes in the structure of production assets.

\section{DISCUSSION}

Analysis of the regulatory and technical base of national standardization in the field of lean production allows us to conclude that it is necessary to comprehensively apply methods and tools of lean production in the activities of a machine-building enterprise. At the same time, in order to achieve the maximum effect, it is necessary to create a management system based on the principles of lean production, based on the process approach and the organization of the value stream, continuous improvement, and staff engagement.

Production systems built on the principles of lean production allow us to reduce costs, increase profitability, increase labor productivity, short lead times, improve flexibility and manageability in changing external and internal conditions.

The formalized model of the production system of a machine-building enterprise is universal and can be adapted to the technological and production capabilities of industrial enterprises to ensure compliance with the requirements of consumers of various types of scientifically advanced products and services.

A full-fledged implementation of the proposed approach to PSD increases the competitiveness of products, contributes to the sustainable development of production, as well as timely response to changes in both external and internal operating conditions of enterprises.

\section{CONCLUSION}

In accordance with the objectives of the study, the analysis of lean production methods has been carried out and the features of their application in scientifically advanced production have been determined.

The results of the analysis, in the long run, can become the basis for the formation of a methodological approach to assessing the level of technological maturity of an enterprise and management potential for the development of production systems.

The classification features formed based on the results of the study in relation to the normative and technical base of standardization in the field of lean production allow us to form a "road map" for the development of lean technologies to improve the efficiency of organizations. Consistent application of lean production standards contributes to the growth of satisfaction of consumers and other interested 
parties both with the quality of the manufactured products and with the price, timing, and rhythm of deliveries.

The proposed standardized model of the production system of a machine-building enterprise based on lean production methods makes it possible to reduce the cost of resources in the activities of the enterprise and production costs and to improve the quality of products. The prospective application of the model should be accompanied by the methods of functional-value and simulation analysis.

The PSD concept increases the competitiveness of the enterprise, contributes to the sustainable development of its production, as well as timely response to emerging risks.

\section{AUTHORS' CONTRIBUTIONS}

The authors made an equal contribution to the study: collection and analysis of material; definition of goals and objectives, research methods; formulation and scientific substantiation of conclusions, registration of key research results in the form of an article.

\section{REFERENCES}

[1] T. Botelho de Sousa, F. Raphael Cabral Furtado, O. Eduardo da Silva Ferri, A. Batista, et al., "Scientific Production on Lean Supply Chains Published in Journals Indexed by SCOPUS and Web of Science Databases: A Bibliometric Study", World Academy of Science, Engineering and Technology, International Journal of Industrial and Manufacturing Engineering, 2018, vol. 12(6), pp. 799-806.

[2] S.Ya. Grodzensky, I.V. Emanakov, S.A. Ovchinnikov "Analysis of losses in production systems - organizational aspect", in Proceedings of the ISPC "Information Innovative Technologies", in Eds. by S.U. Uvaysov,
I.A. Ivanov, Moscow: Association of graduates and employees of AFEA named after prof. Zhukovsky, 2020, pp. 85-89.

[3] S.Ya. Grodzensky, I.V. Emanakov, S.A. Ovchinnikov, "The method of identifying losses in a production system", Science Intensive Technologies, 2018, vol. 19(1), pp. 10-13. (In Russ.).

[4] M. Helmold, B. Terry, "Lean Product Development", Operations and Supply Management 4.0, 2021, pp. 139-143. DOI: 10.1007/978-3-030-68696-3_11

[5] G. Reinhart, J. Greitemann, M. Niehues, "Lean Production", CIRP Encyclopedia of Production Engineering, 2016. DOI: 10.1007/978-3-64235950-7_16831-1

[6] N.S. Davydova, N.V. Grashchenkova, "Lean production management system and sustainability of lean transformations", New Technologies, 2021, vol. 17(2), pp. 121-130. (In Russ.). DOI: 10.47370/2072-0920-2021-17-2121-130

[7] P. Cunningham "Lean productive systems plan", BASICS: Be Always Sure Inputs Create Success, 2020, pp. 7-12. DOI: 10.4324/9781003016328-3

[8] M. Helmold, "Principles of a Lean Production System", Lean Management and Kaizen, 2020, pp. 79-89. DOI: 10.1007/978-3-030-46981-8_9

[9] D. Vaněček, M. Pech, M. Rost, "Innovation and Lean Production", Acta Universitatis Agriculturae et Silviculturae Mendelianae Brunensis, 2018, vol. 66(2), pp. 595-603. DOI: 10.11118/actaun201866020595

[10] I.V. Burenina, "Lean Production Implementation Mechanism", in Proceedings of the II ISC GCPMED 2019 - "Global Challenges and Prospects of the Modern Economic Development", 2019, pp. 140-144. DOI: 10.15405/epsbs.2020.03.1 